REPORTS OF MORPHOLOGY
$\begin{gathered}\text { Official Journal of the Scientific Society of Anatomists, } \\ \text { Histologists, Embryologists and Topographic Anatomists } \\ \text { of Ukraine } \\ \text { journal homepage: https://morphology-journal.com }\end{gathered}$

\title{
Histochemical picture in the skin of rats 1, 3, 7, 14, 21 and 30 days after burning of II-III degrees on the background of injection during first 7 days of $0.9 \% \mathrm{NaCl}$ solution
}

\author{
Maievskyi O.Ye. ${ }^{1}$, Volkov K.S. ${ }^{2}$, Nebesna Z.M. ${ }^{2}$, Mironov Ye.V. ${ }^{1}$, Shayuk A.V. ${ }^{3}$ \\ ${ }^{1}$ National Pirogov Memorial Medical University, Vinnytsya, Ukraine \\ ${ }^{2}$ SHEE "Ternopil Ivan Horbachevsky State Medical University of the Ministry of Healthcare of Ukraine", Ternopil, Ukraine \\ ${ }^{3}$ Zhytomyr Ivan Franko State University, Zhytomyr, Ukraine
}

\section{ARTICLE INFO}

Received: 5 March, 2018

Accepted: 24 April, 2018

UDC: $616-001.17: 615.451 .3$

CORRESPONDING AUTHOR

e-mail: maevskyalex8@gmail.com Maievskyi O. Ye.
For pathogenetically grounded therapy of burn disease, aimed at reducing the severity of the pathological process, the rapid recovery of microcirculation and stimulation of reparative processes, it is necessary to study the fine mechanisms of reparative regeneration in the skin on the microscopic and biochemical levels. The purpose of the study is to investigate the state of elastic and collagen fibers, as well as glycoproteins and glycosaminoglycans in the intercellular substance of the dermis of rats 1, 3, 7, 14, 21 and 30 days after the burning of the II-III degree, with the background of the injection during first 7 days of $0.9 \% \mathrm{NaCl}$ solution. An experimental study of structural changes in the skin after burn injury was performed on laboratory white rats, males weighing 150-160 g. Rats were divided into 2 groups, which previously, under the conditions of propofol anesthesia $60 \mathrm{mg} / \mathrm{kg}$ internally, catheterization of the femoral vein and depilation lateral surfaces of the trunk of rats. Group 1 - animals without thermal trauma of the skin, which once a day for the first 7 days were injected intravenous infusion of $0.9 \%$ $\mathrm{NaCl}$ solution in a dose of $10 \mathrm{ml}$ per $\mathrm{kg}$. Group 2 - animals who were also injected once a day with the first 7 days of infusion of $0.9 \% \mathrm{NaCl}$ solution in a dose of $10 \mathrm{ml}$ per $\mathrm{kg}$ after 2-3 degree skin burns, with a total area of $21-23 \%$ of the body surface of the rat. Euthanasia of rats was performed after propofol anesthesia $(60 \mathrm{mg} / \mathrm{kg} \mathrm{i} / \mathrm{V})$ by decapitation. Changes in the histochemical structure of bits of skin from the edge of the wound were studied after 1, 3, 7, 14, 21, and 30 days from the beginning of the experiment. Histological sections 5-6 microns thick were stained with Weigert's elastic stain and dyed with picric acid by Van Gieson's method (for the detection of elastic and collagen fibers); the PAS + Hale reaction was performed by the Moury method (detection of glycoproteins and glycosaminoglycans in the intercellular substance of the dermis). The histochemical investigations of the area of the II-III degree of skin damaged by burns on the background of the injection of $0.9 \% \mathrm{NaCl}$ solution found that the degree of change depends on the duration of the experiment. In the early stages of the experiment, the reorganization of the intercellular substance of the dermis manifests itself as damage to the fibrous structures of its papillary and reticular layers. Histochemically, the components of amorphous connective tissue substance are dominated by glycoproteins, the content of acidic glycosaminoglycans is small. In the late stages of the experiment (after 14, 21 and 30 days) in the connective tissue of the affected skin in the central and marginal regions poorly structured collagen and elastic fibers are observed. The pronounced "Hale"-positive coloration reflects an increase in the content of sulfated glycosaminoglycans in the amorphous substance of the connective tissue. Thus, the experimental thermal trauma of skin II-III degree on the background of the introduction during the first 7 days, $0.9 \%$ of the $\mathrm{NaCl}$ solution is histochemically characterized by reorganization of the intercellular substance of the connective tissue of the dermis. In the early stages of the experiment there is damage to the fibrous structures of the papillary and reticular layers, the prevalence of glycoproteins and the insignificant content of acidic glycosaminoglycans in the amorphous substance, 
indicating a significant inhibition of adaptive-compensatory processes. In the long term, after the thermal defeat in the dermis, histochemically, an increase in the amount of acid glycosaminoglycans is detected and the PAS positivity of the collagen fibers of the intercellular substance is well expressed. This indicates a slow updating of the amorphous substance and fibrous structures of the connective tissue of the dermis, a violation of regenerative processes.

Keywords: thermal burns of the skin, rats, histochemical studies.

\section{Introduction}

Burns are one of the most common traumatic skin lesions. This is due to an increase in the frequency of their receipt at work, in everyday life, in conditions of regional military conflicts and disasters of peacetime [1, 32].

In the first place, thermal injury damages the skin, because it plays an important role in protecting the body from extreme environmental factors. Damage of the skin is considered to be leading in the development of burn disease, which is complicated by both pathogenesis and treatment, and most importantly - characterized by high mortality $[18,21,33]$.

Burn wound is not a "stable" formation, in the process of repair it is possible to deepen it, it is associated with circulatory disorders and, first of all, with a capillary stasis, which initially causes anoxia of tissues, and then their necrosis [22]. Significant quantitative and qualitative changes in metabolic processes result in endogenous intoxication and associated with a decrease in non-specific resistance of the organism [21, 33].

Timely and complete recovery of the skin needs not only from the point of view of cosmetic and functional effectiveness, but also to save the victim's life. Deepening of the damage to the layers of the skin and deterioration of the patient's condition may occur when irrational treatment [19, 20, 34].

Morphofunctional changes in organs and tissues with thermal burns continue until the healing of burning surfaces [35]. The main issue concerns the dynamics of morphological changes in organs of indicators of homeostasis, infectious process and the regeneration scenario of burned skin. These organs include the lungs, small intestine, kidneys, spleen, etc., the study of structural changes in the modeling of burns of the skin is currently actively conducted $[3,4,7,8,11,13,23]$.

For pathogenetically grounded therapy of burn disease, aimed at reducing the severity of the pathological process, the rapid recovery of microcirculation and stimulation of reparative processes, it is necessary to study the fine mechanisms of reparative regeneration in the skin on the microscopic and biochemical levels [24, 37]. Extrapolation of results obtained on the example of burns in an experiment on laboratory animals is a serious ground for the study of the effectiveness of the use of pharmaceuticals and drugs in the treatment of burn disease [6, 15, 29].

The purpose of the study is to investigate the state of elastic and collagen fibers, as well as glycoproteins and glycosaminoglycans in the intercellular substance of the dermis of rats $1,3,7,14,21$ and 30 days after the burning of the II-III degree, on the background of the injection during first 7 days $0.9 \% \mathrm{NaCl}$ solution.

\section{Materials and methods}

Experimental study of structural changes in the skin after burn injury was performed on laboratory white rats, males weighing 150-160 g obtained from the vivarium of the Institute of Pharmacology and Toxicology of the Academy of Medical Sciences of Ukraine. Animals were kept at the Scientific and Experimental Clinic of the National Pirogov Memorial Medical University, Vinnytsya on a standard diet, with free access to water and food. The temperature in the room where the animals were kept was $24-25{ }^{\circ} \mathrm{C}$. The research was conducted on the basis of the research laboratory of functional morphology and genetics of the development of the research center of the National Pirogov Memorial Medical University, Vinnytsya and in the laboratory of the department of pharmacology of the National Pirogov Memorial Medical University, Vinnytsya.

Bioethics Committee of National Pirogov Memorial Medical University, Vinnytsya determined that the experiments were carried out taking into account the recommendations of the European Commission regarding medical and biological research using animals, medical recommendations of the State Pharmacological Center of the Ministry of Health of Ukraine and "Rules for the clinical evaluation of safety of pharmacological agents (GLP)".

The rats were divided into 2 groups, which previously, under the conditions of propofol anesthesia $60 \mathrm{mg} / \mathrm{kg}$ internally, catheterization of the femoral vein and depilation of the lateral surfaces of the trunk of the rats were performed.

Group 1 - animals without thermal trauma of the skin, which once a day for the first 7 days were administered intravenous infusion of $0.9 \% \mathrm{NaCl}$ solution in a dose of 10 $\mathrm{ml}$ per kg.

Group 2 - animals that were also treated once a day with for first 7 days with infusion of $0.9 \% \mathrm{NaCl}$ solution, at a dose of $10 \mathrm{ml}$ per $\mathrm{kg}$ after burning the skin. The burnout shock was caused by applying to the shaved lateral surfaces of the trunk of the rats four copper plates (two plates on each side), which were preheated for 6 minutes in water at a constant temperature of $100{ }^{\circ} \mathrm{C}$. [14, 28]. The surface area of each plate was $13.86 \mathrm{sm}^{2}$. The total area of defeat, calculated by the formula M. O. Lee [25], was 21$23 \%$ of the body surface of rats. Such an area the exposure of 10 seconds is sufficient for the formation of a 
2-3 degree burn (according to the classification adopted at the 20th Congress of Surgeons of Ukraine, September 2000 in Ternopil.) And causing a medium-gravity shock state [31], which has been confirmed by team of performers of the scientific work of the research center of the National Pirogov Memorial Medical University, Vinnytsya "Structural changes in the lungs in the conditions of endogenous intoxication caused by skin burn and its correction with domestic infusion drugs "lactoprotein with sorbitol" and HAES-LX-5\% (experimental study)" (State Registration No. 0112U004187) [12]. Euthanasia of rats was performed after propofol anesthesia $(60 \mathrm{mg} / \mathrm{kg} \mathrm{i} / \mathrm{v})$ by decapitation. Changes in the histochemical structure of the skin were studied 1,3 , $7,14,21$, and 30 days from the beginning of the experiment.

After decapitation for 5 minutes, they took pieces of skin from the edge of the wound to fix the material before the development of posthumous changes. Sections were fixed in $10 \%$ formalin solution, while the exposure time did not exceed 1-2 days. Subsequently, dehydration was carried out in spirits of increasing concentration and poured into paraffin blocks. Received on the sledge microtome MS-2 histological sections 5-6 microns thick were stained with Weigert's elastic stain and dyed with picric acid by Van Gieson's method (for the detection of elastic and collagen fibers); the PAS + Hale reaction was performed by the Moury method (detection of glycoproteins and glycosaminoglycans in the intercellular substance of the dermis) [9, 30]. Histochemical slides were investigated in a light microscope of Leitz Laborlux S.

\section{Results}

In the papillary layer of skin dermis of intact animals, thin elastic fibers are observed, which anastomosises between themselves and thicker wave-shaped undifferentiated collagen fibers (Fig. 1).

When conducting histochemical studies of the skin of white rats of the control group in the intercellular substance of its connective tissue, brightly "Hale"-positive acidic glycosaminoglycans and moderately PAS-positive glycoproteins, neutral glycosaminoglycans (Fig. 2).

In the early stages after burn injury in the intercellular substance of the connective tissue there is swelling and thickening of collagen fibers, their homogenization, destruction of elastic fibers and decay into fragments (Fig. 3). Histochemical changes in the amorphous substance of the dermis appear to be insignificant "Hale"-positive color and pronounced PAS-positive properties, indicating the disintegration of glycosaminoglycans and an increase in the number of glycoproteins (Fig. 4).

After 7 and 14 days of the experiment on preparations prepared by the Van Gieson's-Weigert's method, defective fibrous structures of the papillary and reticular skin dermis are observed at the site of the lesion. Elastic fibers are not detected (Fig. 5).

In the amorphous substance of the dermis, the predominance of glycoproteins and a small amount of

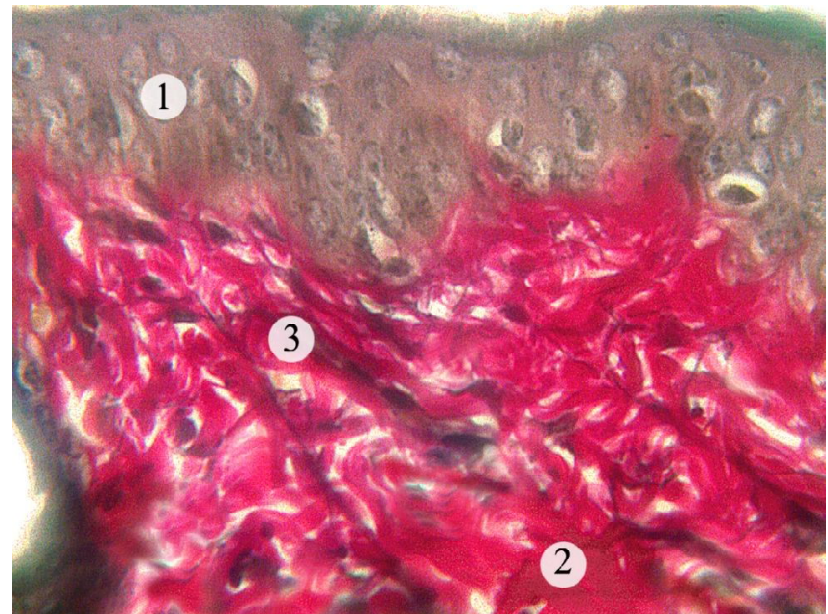

Fig. 1. Histological organization of the skin of the animal intact group. Epidermis (1), collagen (2) and elastic (3) fibers of the papillary layer of the dermis. Van Gieson's-Weigert's coloring. $x$ 600.

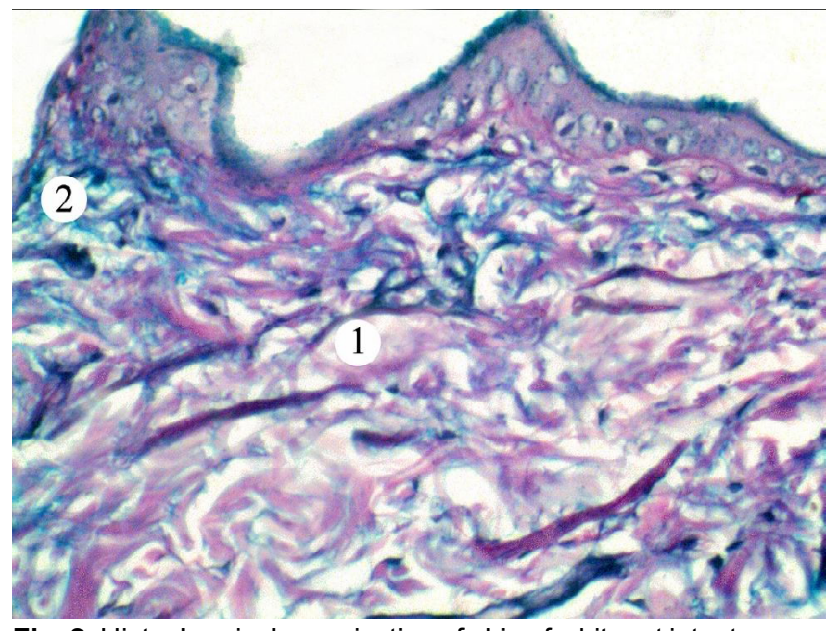

Fig. 2. Histochemical organization of skin of white rat intact group. Moderately PAS-positive collagen fibers (1) and bright "Hale"positive sour glycosaminoglycans (2) amorphous dermis substances. Coloring by the Moury method. x 300 .

acidic glycosaminoglycans was revealed histochemically, manifested by pronounced PAS-positive properties and an insignificant "Hale"-positive color (Fig. 6).

In the late stages of the experiment (21 and 30 days) in preparations painted on the Van Gieson's-Weigert's method poorly structured collagen and fragmented elastic fibers are observed in the reticular layer of the connective tissue of the skin (Fig. 7). The histochemical increase in the amount of sulfated glycosaminoglycans in the amorphous substance of the dermis, which may be due to an increase in the synthetic activity of fibroblasts. There is a wellexpressed PAS-positivity of collagen fibers (Fig. 8).

\section{Discussion}

In intact skin, the fibrous structures of the dermis consist of collagen, elastic and reticular fibers. The intervals between fibers, appendages of the skin and other structural 


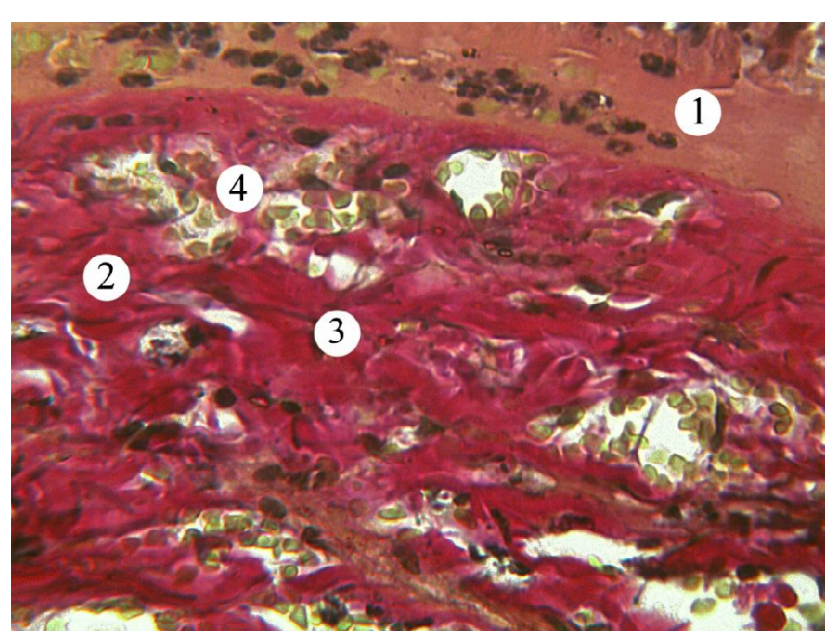

Fig. 3. Histological changes in the skin of animals after 1 day after a thermal trauma. Necrotically altered epidermis (1), thickened collagen fibers (2), fragmented elastic fibers (3), hemocapillaries (4). Van Gieson's-Weigert's coloring. x 400.

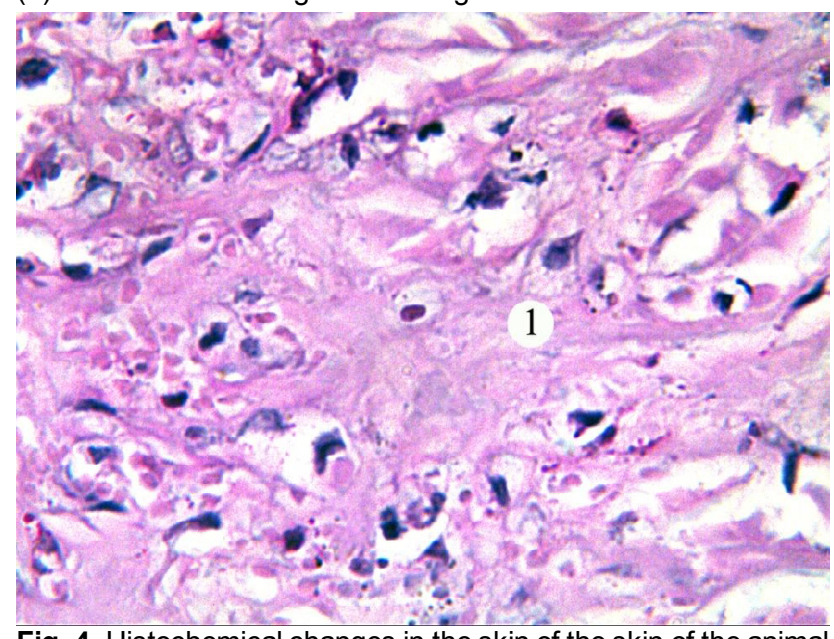

Fig. 4. Histochemical changes in the skin of the skin of the animal after 3 days after a thermal trauma. Swollen collagen fibers (1) with pronounced PAS-positive properties. Coloring by the Moury method.x 400

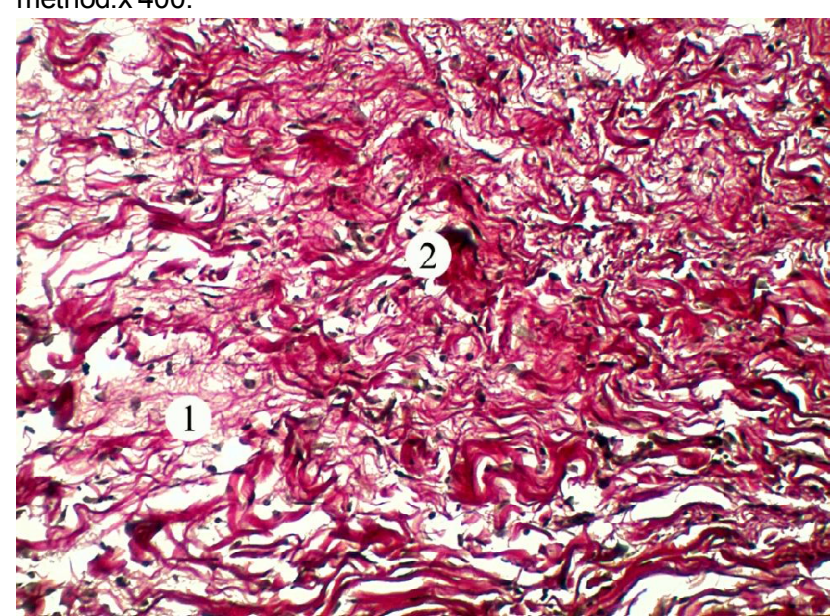

Fig. 5. Histological changes in the skin of the animal 7 days after burn injury. Damaged, thin, unstructured collagen fibers (1), altered fibroblasts (2). Van Gieson's-Weigert's coloring. x 300.

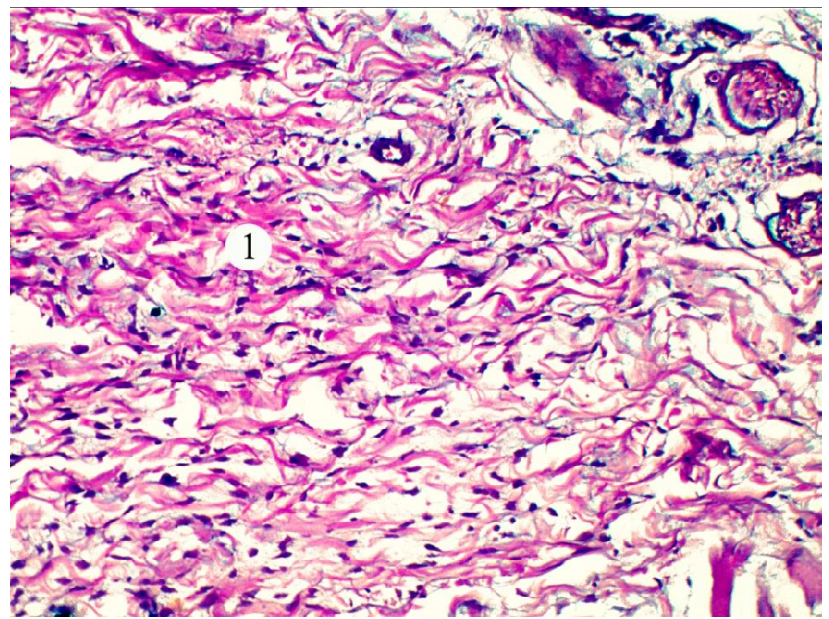

Fig. 6. Histochemical changes of the derma of the animal 7 days after a thermal trauma. PAS-positive collagen fibers (1). Coloring by the Moury method.x 300 .

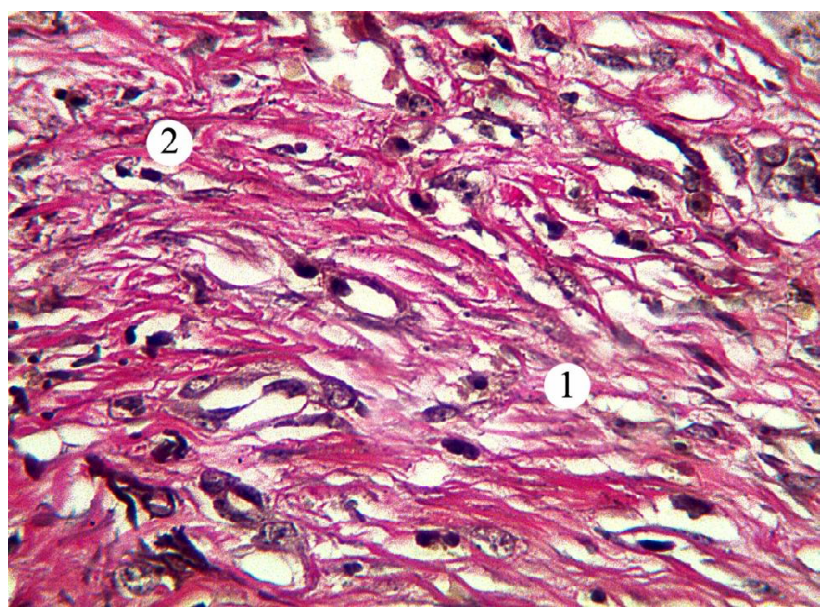

Fig. 7. Histological changes in the skin of the animal after 21 days after a thermal trauma. Collagen (1) and elastic fibers (2). Van Gieson's-Weigert's coloring. x600.

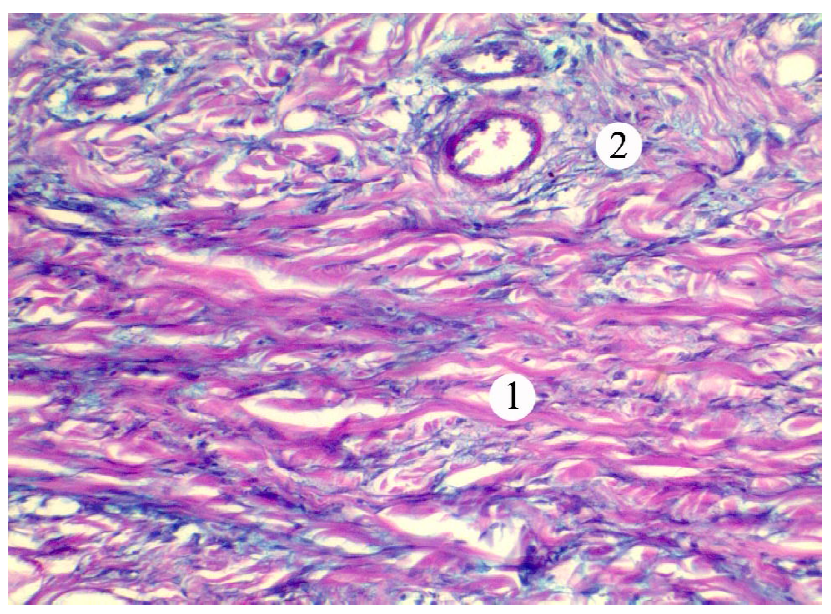

Fig. 8. Histochemical organization of skin of an animal 21 days after a thermal trauma. Components of the dermis with wellexpressed PAS- (1) and "Hale"-positive (2) properties. Coloring by the Moury method. $x 200$. 
formations are the so-called basic substance - an amorphous substance, the important components of which are glycoproteins and glycosaminoglycans [2].

At burns of II-III degree there are changes in the structure of elastic and collagen fibers, and also the balance of glycoproteins and glycosaminoglycans in the intercellular substance of the skin dermal layer [16] is disturbed. The fiber architecture, the ratio of glycosaminoglycans and glycoproteins, the fibrous component, and the cell proliferation are markers of the favorable flow of the wound process and the effectiveness of the use of drugs [17].

Having made a search cut of literary data it is established that prognostically it is beneficial:

A) when staining by Weigert's and dyeing with picric acid by Van Gieson's [30]: ordering collagen fibers and reducing their swelling, the appearance in the regenerate of elastic fibers (within a month of observation) [10, 15, 29]; predominance of the fibrous component over cell proliferate (fibroblasts), the formation of an amorphous component, which indicates the high degree of maturity of the granulation tissue (predominantly for 14 days) [5, 16, 33]; formation of the dermal plate, which is mainly represented by mature fibrous connective tissue consisting of fuchsinophilic beams of collagen fibers, infiltrated fibroblast cells (after 1 month) [26, 27, 35].

$B$ ) in the implementation of the PAS + "Hale" reaction by the Moury method [15, 17]: structuring of glycosaminoglycans $[13,36]$; reduced expression of the PASpositive properties of granulation tissue (reduction of glycoproteins) and the "Hale"-positive strengthening of the connective tissue in the area of the burn wound (increase of acidic glycosaminoglycans) by 14-21 days compared with the previous terms of the experiment [22, 37].

The histochemical investigations made by us of the area of the II-III degree of skin that was damaged by burns on the background of the introduction of a $0.9 \%$ solution of $\mathrm{NaCl}$ found that the degree of change depends on the duration of the experiment. In the early stages of the experiment (after 1 , 3 and 7 days) the reorganization of the intercellular substance of the dermis manifests itself as damage to the fibrous structures of its papillary and reticular layers. Histochemically,

\section{References}

[1] Bikova, I. Yu., Yefimenko, N. A., \& Gumanenko, Ye. K. (2009). Field Surgery: national guide. M. : GEOTAR - Media.

[2] Breitkreutz, D., Mirancea, N., \& Nischt, R. (2009). Basement membranes in skin: unique matrix structures with diverse functions? Histochem. Cell. Biol., 132(1), 1-10. doi: 0.1007/ s00418-009-0586-0

[3] Chaikovskii, Yu. B., Korol, A. P., \& Makarova., O. I. (2014). Ultrastructural features of respiratory tract lungs of rats in remote period after thermal burn its skin. Biomedical and Biosocial Anthropology, 23, 57-62.

[4] Chaikovskii, Yu. B., Makarova., O. I., Chereshniuk, I. L., \& Lysenko, D. A. (2014). Comparative characteristics of cell cycle and DNA fragmentation of lung cells in rats after skin burn injury. World of Medicine and Biology, 2(44), 181-185.

[5] Delavary, B. M., van der Veer, W. M., van Egmond, M., Niessen, F. B., \& Beelen, R. H. J. (2011). Macrophages in skin injury and among the components of amorphous connective tissue substance is dominated by glycoproteins, the content of acid glycosaminoglycans is small, which indicates their lesion.

After experimental thermal trauma in the late stages of the experiment (after 14, 21 and 30 days), colored preparations using the Van Gieson's-Weigert's method in the connective tissue of the affected skin in the central and boundary regions of the poorly structured collagen and elastic fibers are observed. The pronounced "Hale"-positive color reflects an increase in the content of sulfated glycosaminoglycans in the amorphous substance of the connective tissue. The revealed histochemical changes are associated with non-fibrotic processes in the burn wound and suggest that the development of young granulation tissue, its maturation and transformation into connective tissue is poorly expressed.

In the future, it is promising to study the state of elastic and collagen fibers, as well as glycoproteins and glycosaminoglycans in the intercellular substance of the dermis of rats after its burn injury on the background of preliminary administration of colloidal hyperosmolar solutions.

\section{Conclusions}

1. Experimental thermal trauma of skin of II-III degrees on the background of the injection during first 7 days of $0.9 \%$ $\mathrm{NaCl}$ solution is histochemically characterized by reorganization of the intercellular substance of the connective tissue of the dermis. In the early stages of the experiment there is damage to the fibrous structures of the papillary and mesenteric layers, the prevalence of glycoproteins and the insignificant content of acidic glycosaminoglycans in the amorphous substance, indicating a significant inhibition of adaptive-compensatory processes.

2. In the long term, after the thermal defeat in the dermis, histochemically, an increase in the amount of acidic glycosaminoglycans is detected and the PAS-positivity of the collagen fibers of the intercellular substance is well expressed. This indicates a slow updating of the amorphous substance and fibrous structures of the connective tissue of the dermis, a violation of regenerative processes.

repair. Immunobiology, 216(7), 753-762. doi: 10.1016/ j.imbio.2011.01.001

[6] Fatemi, M. J., Momeni, M., Tavakoli, A., Bagheri, T., Hosseini, A., Araghi, S., ... Zavareh, A. (2018). Treatment of third-degree burn wounds in animal specimens: acellular dermis or partialthickness skin graft. Ann. Burns Fire Disasters, 31(2), 144148. PMID: 30374268

[7] Galunko, G. M. (2017). Histological changes in the small intestine in the advanced stages of burn disease. World of Medicine and Biology, 3(61), 90-96. doi: 10.26724 / 2079-8334-2017-361-90-96

[8] Gavryluk, A. O., Gunas, I. V., Galunko, G. M., Chereshniuk, I. L., \& Lysenko, D. A. (2017). Indicators of the cell cycle and fragmentation of DNA of cells of small intestinal mucosa through 14, 21 and 30 days after burn skin damage on the background of infusion of $0,9 \% \mathrm{NaCl}$ solution. Biomedical and Biosocial 
Anthropology, 29, 104-108.

[9] Goralskiy, L. P., Homich, V. T., \& Kononskiy, O. I. (2011). Fundamentals of histological technique and morphofunctional methods of research in norm and in pathology. Zhitomir: Polissya.

[10] Grin, I. V., Zvyaginceva, T. V., Naumova, O. V., \& Grin, V. V. (2015). Influence of tiotriazolin ointment with nanoparticles of silver on morphological changes of skin of rats after thermal burn. Clinical Pharmacy, Pharmacotherapy and Medical Standardization, 3-4(27-28), 126-130.

[11] Gunas, I. V., Guminskiy, Yu. I., Ocheretna, N. P., Lysenko, D. A., Kovalchuk, O. I., Dzevulska, I. V., \& Cherkasov, E. V. (2018). Indicators cell cycle and dna fragmentation of spleen cells in early terms after thermal burns of skin at the background of introduction $0.9 \% \mathrm{NaCl}$ solution. World of Medicine and Biology, 1(63), 116-120. doi: 10.26.724/2079-8334-2018-1-63-116-120

[12] Gunas, I. V., Kondratskiy, B. O., Nurmetova, I. K., Dzevulska, I. V., Kovalchuk, O. I., Cherkasov, Ye. V., ... \& Sitnik, O. V. (2012). Dynamics of changes in the level of endogenous intoxication in rats organisms for a month after the skin burn of II-III degree, $21-23 \%$ of the body surface area and its correction by infusion solutions of Lactoprotein with sorbitol and HAES-LX-5\%. Ukrainian morphological almanac, 10(4), 29-34.

[13] Gunas, I. V., Ocheretnyuk, A. O., Chereshniuk, I. L., \& Lysenko, D. A. (2013). Features of cell cycle and lung cell DNA fragmentation in rats within 1,3 and 7 days after skin burns. Clinical and experimental morphology, 3(7), 38-43.

[14] Gunas, I., Dovgan, I., \& Masur, O. (1997). Method of thermal burn trauma correction by means of cryoinfluence. Abstracts are presented in zusammen mit der Polish Anatomical Society with the participation of the Association des Anatomistes Verhandlungen der Anatomischen Gesellschaft, Olsztyn ( $p$. 105). Jena - Munchen : Der Urban \& Fischer Verlag.

[15] Gurtner, G. C., Werner, S., Barrandon, Y., \& Longaker, M. T. (2008). Wound repair and regeneration. J. Nature, 453, 314321. doi: $10.1038 /$ nature 07039

[16] Hoganson, D. M., O'Doherty, E. M., Owens, G. E., Harilal, D. O., Goldman, S. M., Bowley, C. M., ... Vacanti, J. P. (2010). The retention of extracellular matrix proteins and angiogenic and mitogenic cytokines in a decellularized porcine dermis. Biomaterials, 31(26), 6730-6737. doi: 10.1016/j.biomaterials.2010.05.019

[17] Imasheva, A. K., \& Lazko, M. V. (2009). Features of the regenerative processes of the skin during thermal burns. Basic research, 5, 22-24.

[18] Kallinen, O., Maisniemi, K., Bohling, T., Tukiainen, E., \& Koljonen, V. (2012). Multiple organ failure as a cause of death in patients with severe burns. J. Burn Care Res, 33(2), 206-211. doi: 10.1097/BCR.0b013e3182331e73

[19] Kearney, L., Francis, E. C., \& Clover, A. J. (2018). New technologies in global burn care - a review of recent advances. Int. J. Burns Trauma, 8(4), 77-87. PMID: 30245912

[20] Kozinets, G. P., Cigankov, V. P., \& Kovalenko, O. M. (2012). Modern infusion therapy in burn shock. Ukrainian Journal of Hematology and Transfusiology, 4, 39-42.

[21] Kraft, R., Herndon, D. N., Al-Mousawi, A. M., Williams, F. N., Finnerty, C. C., \& Jeschke, M. G. (2013). Burn size and survival probability in pediatric patients in modern burn care. Lancet, 379(9820), 1013-1021. doi: 10.1016/S0140-6736(11)61345-7

[22] Kramar, S. B., \& Volkov, K. S. (2014). Histologic and histochemical changes of the damaged area of the skin in the dynamics after the experimental thermal trauma. Journal of Medical and Biological Problems, 4(46), 182-185.

[23] Lachtadyr, T. V. (2017). Structural changes of rat's renal cortex in late period of skin burn injury under the conditions of the infusion by isotonic Natrium cloridum solution. Reports of Morphology, 23(2), 211-218.

[24] Lataillade, J., Bey, E., Thepenier, C., Prat, M., Leclerc, T., \& Bargues, L. (2010). Skin engineering for burns. Bull. Acad. Nat. Med., 194(7), 1339-1351. PMID: 22043629

[25] Lee, M. O. (1989). Determination of the surface area of the white rat with its application to the expression of metabolic results. Am. J. Physiol., 24, 1223. https://doi.org/10.1152/ ajplegacy.1929.89.1.24

[26] Musina, L. A., \& Nurayeva, A. B. (2015). Healing of burn wounds with the use of allogeneic biomaterials (experimental morphological study). Bulletin of the Orenburg State University, 12(187), 142-145.

[27] Pereira, R. F., Barrias, C. C., Granja, P. L., \& Bartolo, P. J. (2013). Advanced biofabrication strategies for skin regeneration and repair. Nanomedicine (Lond), 8(4), 603-621. doi: 10.2217/ nnm.13.50

[28] Regas, F. C., \& Ehrlich, H. P. (1992). Elucidating the vascular response to burns with a new rat model. J. Trauma, 32, 5, 557563. PMID: 1588642

[29] Rnjak, J., Weiss, S. G., Mithieux, S. M., \& Weiss A. S. (2011). Severe burn injuries and the role of elastin in the design of dermal substitutes. Tissue Engineering Part B Reviews, 17(2), 81-91. doi: 10.1089/ten.TEB.2010.0452

[30] Sarkisov, D. S., \& Perova, Yu. L. (1996). Microscopic technique. M.: Medicine.

[31] Schano, V. P., Grin, V. K., Fistal, E. Ya., Miminoshvili, O.I., Zayats, Yu.V., \& Chorniy, V. I. (2006). Burn shock. Donetsk: Southeast.

[32] Shapovalov, V. M., \& Gladkov, R. V. (2014). Peacetime blast damage: epidemiology, pathogenesis and major clinical manifestations. Biomedical and socio-psychological problems of safety in the extreme situations, 3, 5-16.

[33] Shi, H., Weng, T., Han, C., \& Wang, X. (2018). Improved Dermal Regeneration Using a Combination of Dermal Substitutes and Dermal Fibroblast Optimization: A Hypothesis. Med. Sci. Monit., 24, 5457-5461. doi: 10.12659/MSM.909743

[34] Swanson, J. W., Otto, A. M., Gibran, N. S., Klein, M. B., Kramer, C. B., Heimbach, D. M., \& Pham, T. N. (2013). Trajectories to death in patients with burn injury. J. Trauma Acute Care Surg., 74(1), 282-288. doi: 10.1097/TA.0b013e3182788a1c

[35] van der Veen, V. C., van der Wal, M. B., van Leeuwen, M. C., Ulrich, M. M., \& Middelkoop, E. (2010). Biological background of dermal substitutes. Burns, 36(3), 305-321. doi: 10.1016/ j.burns.2009.07.012

[36] Voigt, J., \& Driver, V. R. (2012). Hyaluronic acid derivatives and their healing effect on burns, epithelial surgical wounds, and chronic wounds: a systematic review and metaanalysis of randomized controlled trials. Wound Repair Regen, 20(3), 317331. doi: 10.1111/j.1524-475X.2012.00777.x

[37] Woodley, D. T. (2017). Distinct Fibroblasts in the Papillary and Reticular Dermis: Implications for Wound Healing. Dermatol. Clin., 35(1), 95-100. doi: 10.1016/j.det.2016.07.004

ГІСТОХІМІЧНА КАРТИНА В ШКІРІ ЩУРІВ ЧЕРЕЗ 1, 3, 7, 14, 21 ТА 30 ДІБ ПІСЛЯ ОПІКУ ІІ-ІІІ СТУПЕНЯ НА ФОНІ ВВЕДЕННЯ ПЕРШИХ 7 ДІБ 0,9 \% РОЗЧИНУ NACL

Маєвський О. Є., Волков К. С., Небесна З. М., Міронов Є. В., Шаюк А. В.

Для патогенетично обгрунтованої терапії опікової хвороби, спрямованої на зниження вираженості патологічного процесу, 
якнайшвидшого відновлення мікроциркуляції і стимуляції репаративних процесів необхідне вивчення тонких механізмів репаративної регенерації в шкірі на мікроскопічному і біохімічному рівні. Мета дослідження - вивчити стан еластичних і колагенових волокон, а також глікопротеїнів і глікозаміногліканів у міжклітинній речовині дерми щурів через 1, 3, 7, 14, 21 та 30 діб після опіку II-III ступеня на фоні введення перших 7 діб 0,9 \% розчину $\mathrm{NaCl}$. Експериментальне дослідження структурних змін шкіри після ї опікового ураження були виконані на лабораторних білих щурах-самцях масою 150-160 г. Щурі були розподілені на 2 групи, в яких попередньо, в умовах пропофолового наркозу 60 мг/ке внутрішньо, проводили катетеризацію стегнової вени та депіляцію бічних поверхонь тулуба щурів. 1 група - тварини без термічної травми шкіри яким 1 раз на добу перші 7 діб проводили внутрішньовенну інфузію 0,9 \% розчину $\mathrm{NaCl}$ у дозі 10 мл на ке. 2 група - тварини яким також проводили 1 раз на добу перші 7 діб інфрузію 0,9 \% розчину $\mathrm{NaCl}$, у дозі 10 мл на ке після опіку шкіри 2-3 ступеню загальною площею ураження 21-23 \% поверхні тіла щурів. Евтаназію щурів проводили після пропофолового наркозу (60 ме на ке в/в) шляхом декапітації. Зміни гістохімічної структури шматочків шкіри з крайової ділянки рани вивчали через 1, 3, 7, 14, 21, та 30 діб від початку експерименту. Гістологічні зрізи товщиною 5-6 мкм забарвлювали фуксиліном за Вейгертом та дофарбовували пікрофуксином за методом Ван Гізона (для виявлення еластичних та колагенових волокон); проводили ШЙК+"Хейл" реакцію за методом Моурі (виявлення глікопротеїнів та глікозаміногліканів у міжклітинній речовині дерми). Проведені гістохімічні дослідження ділянки пошкодженої опіком ІІ-ІІІ ступеня шкіри на ороні введення 0,9 \% розчину $\mathrm{NaCl}$ встановили, що ступінь змін залежить від терміну досліду. У ранні терміни експерименту реорганізація міжклітинної речовини дерми проявляється пошкодженням волокнистих структур ї сосочкового і сітчастого шарів. Гістохімічно серед компонентів аморфної речовини сполучної тканини переважають глікопротеїни, вміст кислих глікозаміногліканів невеликий. У пізні терміни досліду (через 14, 21 та 30 діб) у сполучній тканини ураженої шкіри в центральних і крайових ділянках спостерігаються погано структуровані колагенові та еластичні волокна. Виражене "Хейл"-позитивне забарвлення відображає збільшення вмісту сульфатованих глікозаміногліканів у аморфній речовині сполучної тканини. Таким чином експериментальна термічна травма шкіри II-III ступеня на фоні введення перших 7 діб 0,9 \% розчину $\mathrm{NaCl}$ гістохімічно характеризується реорганізацією міжклітинної речовини сполучної тканини дерми. У ранні терміни досліду відбувається пошкодження волокнистих структур сосочкового і сітчастого шарів, переважання глікопротеїнів та незначний вміст кислих глікозаміногліканів у аморфній речовині, що свідчить про значне пригнічення пристосувально-компенсаторних процесів. У віддалені терміни після термічного ураження у дермі гістохімічно виявляється збільшення кількості кислих глікозаміногліканів та добре виражена Шйк-позитивність колагенових волокон міжклітинної речовини. Це свідчить про повільне оновлення аморфної речовини і волокнистих структур сполучної тканини дерми, порушення регенераторних процесів.

Ключові слова: термічний опік шкіри, щури, гістохімічні дослідження.

\section{ГИСТОХИМИЧЕСКАЯ КАРТИНА В КОЖЕ КРЫС ЧЕРЕЗ 1, 3, 7, 14, 21 И 30 СУТОК ПОСЛЕ ОЖОГА ІІ-ІІІ СТЕПЕНИ НА ФОНЕ ВВЕДЕНИЯ ПЕРВЫХ 7 ДНЕЙ 0,9\% РАСТВОРА NACL \\ Маевский А. Е., Волков К. С., Небесная 3. М., Миронов Е. В., Шаюк А. В.}

Для патогенетически обоснованной терапии ожоговой болезни, направленной на снижение выраженности патологического процесса, скорейшего восстановления микроциркуляции и стимуляции репаративных процессов необходимо изучение тонких механизмов репаративной регенерации в коже на микроскопическом и биохимическом уровне. Цель исследования - изучить состояние эластических и коллагеновых волокон, а также гликопротеинов и гликозаминогликанов в межклеточном веществе дермы крыс через 1, 3, 7, 14, 21 и 30 суток после ожога II-III степени на фоне введения первых 7 дней 0,9\% раствора NaCl. Экспериментальное исследование структурных изменений кожи после ее ожогового поражения были выполнены на лабораторных белых крысахсамцах массой 150-160 г. Крысы были разделены на 2 группы, в которых предварительно, в условиях пропофолового наркоза 60 мг/ кә внутрь, проводили катетеризацию бедренной вены и депиляцию боковых поверхностей туловища крыс. 1 группа - животные без термической травмы кожи которым 1 раз в сутки первые 7 суток проводили инфузию 0,9\% раствора NaCl в дозе 10 мл на кट. 2 группа - животные, которым также проводили 1 раз в сутки первые 7 суток инфузию 0,9\% раствора NaCl в дозе 10 мл на ке после ожога кожи 2-3 степени общей площадью поражения 21-23\% поверхности тела крыс. Эвтаназию крыс проводили после пропофолового наркоза (60 мг на кг в/в) путем декапитации. Изменения гистохимической структуры кусочков кожи с краевого участка раны изучали через 1, 3, 7, 14, 21 и 30 суток от начала эксперимента. Гистологические срезы толщиной 5-6 мкм окрашивали фруксилином по Вейгерту и докрашивают пикрофуксином по методу Ван Гизона (для выявления эластичных и коллагеновых волокон); проводили ШИК+"Хейл" реакцию методом Моури (выявление гликопротеинов и гликозаминогликанов в межклеточном веществе дермы). Проведенные гистохимические исследования участка поврежденной ожогом II-ІІІ степени кожи на фроне введения 0,9\% раствора $\mathrm{NaCl}$ установили, что степень изменений зависит от срока опыта. В ранние сроки эксперимента реорганизация межклеточного вещества дермы проявляется повреждением волокнистых структур ее сосочкового и сетчатого слоев. Гистохимически среди компонентов аморфного вещества соединительной ткани преобладают гликопротеины, содержание кислых гликозаминогликанов невелико. В поздние сроки опыта (через 14, 21 и 30 суток) в соединительной ткани пораженной кожи в центральных и краевых участках наблюдаются плохо структурированные коллагеновые и эластичные волокна. Выраженное "Хейл"-положительное окрашивание отражает увеличение содержания сульфатированных гликозаминогликанов в аморфном веществе соединительной ткани. Таким образом, экспериментальная термическая травма кожи II-III степени на фроне введения первых 7 дней 0,9\% раствора $\mathrm{NaCl}$ гистохимически характеризуется реорганизацией межклеточного вещества соединительной ткани дермы. В ранние сроки опыта происходит повреждение волокнистых структур сосочкового и сетчатого слоев, преобладание гликопротеинов и незначительное содержание кислых гликозаминогликанов в аморфной веществе, что свидетельствует о значительном подавлении приспособительно-компенсаторных процессов. В отдаленные сроки после термического поражения в дерме гистохимически выявляется увеличение количества кислых гликозаминогликанов и хорошо выраженная ШИК-позитивность коллагеновых волокон межклеточного вещества. Это свидетельствует о медленном обновлении аморфного вещества и волокнистых структур соединительной ткани дермы, нарушения регенераторных процессов.

ключевые слова: термический ожог кожи, крысы, гистохимические исследования. 